\section{Air pollution and children's health: sickle cell
disease \\ Air pollution and children's health: sickle cell
disease}

\author{
Poluição do ar e a saúde das crianças: a doença \\ falciforme
}

\section{Contaminación atmosférica y salud de los niños: la \\ enfermedad de células falciformes}

\author{
1 Faculdade de Medicina, \\ Universidade de São Paulo, \\ São Paulo, Brasil. \\ 2 Programa de Pós-graduação \\ em Saúde Coletiva, \\ Universidade Católica de \\ Santos, Santos, Brasil. \\ ${ }^{3}$ Exposure Epidemiology \\ and Risk Program, Harvard \\ School of Public Health, \\ Boston, U.S.A. \\ Correspondence \\ S. M. M. Barbosa \\ Laboratório de Poluição \\ Atmosférica Experimental, \\ Faculdade de Medicina, \\ Universidade de São Paulo. \\ Av. Dr. Arnaldo 455, 1o andar, \\ sala 1304, São Paulo, SP \\ 01246-903, Brasil. \\ silmmb@gmail.com
}

\begin{abstract}
The hallmarks of sickle cell disease are anemia and vasculopathy. The aim of this study was to assess the association between air pollution and children's emergency room visits of sickle cell patients. We adopted a case-crossover design. Daily counts of children's and adolescents' sickle cell disease emergency room visits from the pediatric emergency unit in São Paulo, Brazil, were evaluated from September 1999 to December 2004, matching by temperature, humidity and controlling for day of the week. Interquartile range increases of the four-day moving averages of $\mathrm{PM}_{10}, \mathrm{NO}_{2}, \mathrm{SO}_{2}, \mathrm{CO}$, and $\mathrm{O}_{3}$ were associated with increases of 18.9\% (95\%CI: 11.2-26.5), 19\% (95\%CI: 8.3-29.6), 14.4\% (95\%CI: 6.5-22.4), 16,5\% (95\%CI: 8.9-24.0), and 9.8\% (95\%CI: 1.1 18.6) in total sickle cell emergency room visits, respectively. When the analyses were stratified by pain, $P M_{10}$ was found to be $40.3 \%$ higher than in sickle cell patients without pain symptoms. Exposure to air pollution can affect the cardiovascular health of children and may promote a significant health burden in a sensitive group.
\end{abstract}

Air Pollution; Sickle Cell Disease; Emergency Medical Services
Silvia Maria de Macedo Barbosa ${ }^{1}$

Sylvia Costa Lima Farhat 1

Lourdes Conceição Martins 1,2

Luiz Alberto Amador Pereira 1,2

Paulo Hilário Nascimento Saldiva 1

Antonella Zanobetti 3

Alfésio Luís Ferreira Braga 1,2

\section{Resumo}

O objetivo deste estudo foi avaliar a associação entre a poluição do ar e atendimentos de emergência pediátrica de pacientes portadores de anemia falciforme. Adotamos um estudo de case-crossover. Visitas de crianças e adolescentes portadores de anemia falciforme ao prontosocorro pediátrico, em São Paulo, Brasil, foram avaliadas a partir de setembro de 1999 até dezembro de 2004, controlando a temperatura, umidade e dia da semana. Variações interquartis das médias móveis de quatro dias de $\mathrm{PM}_{10}, \mathrm{NO}_{2}$, $\mathrm{SO}_{2}$, $\mathrm{CO}$ e $\mathrm{O}_{3}$ foram associadas com aumentos de 18,9\% (IC95\%: 11,2-26,5), 19\% (IC95\%: 8,3-29,6), 14,4\% (IC95\%: 6,5-22,4), 16,5\% (IC95\%: 8,9-24,0) e 9,8\% (IC95\%: 1,1-18,6) nos atendimentos totais, respectivamente. Quando as análises foram estratificadas por dor, verificou-se que $P M_{10}$ apresentou correlação 40,3\% maior do que a observada em pacientes falciformes sem sintomas de dor. A exposição à poluição do ar pode afetar a saúde cardiovascular de crianças e promover um fardo significativo para a saúde em um grupo suscetivel, como o de pacientes com anemia falciforme.

Poluição do Ar; Anemia Falciforme; Serviços Médicos de Emergência 


\section{Introduction}

Fossil fuel combustion represents a major source of air pollution nowadays 1,2. Fine particles are those with diameters smaller than $2.5 \mu \mathrm{m}$, while ultrafine particles have a diameter smaller than $0.1 \mu \mathrm{m}$. A significant portion of these particles is composed of sulfates, nitrates, hydrocarbons, benzene, toluene, metals and other substances in their adsorbed molecules. The exposure to fine and ultrafine particles (UFPs) by complex molecular events can trigger pulmonary oxidative stress and inflammation 1,3,4, and can contribute to a state of systemic inflammation. Indeed, the latest statement from the American Heart Association 3 considered that inhalation of particulate matter can lead to extra-pulmonary effects on three cardiovascular system by three pathways: Pathway 1 - the release of vasculoactive molecules or pro-inflammatory mediators from lung based cells; Pathway 2 - imbalance of the autonomic nervous system by particle interactions with lung receptors or nerves; Pathway 3 - potentially the translocation of UFPs or particle constituents (organic compounds, metals) into the systemic circulation.

Recent studies have shown alterations in systemic inflammation and biomarkers (interleukin-6, TNF alpha, C-reactive protein, fibrinogen and plasminogen activator inhibitor-1, interleukin-1 beta, and endothelin-1) after exposure to air pollutants $5,6,7,8,9,10,11,12,13,14$. Oxidative stress and inflammation induced by inhaled pollutants may lead to acute and chronic effects in the respiratory system, chronic inflammatory diseases such as cardiovascular, neurodegenerative and auto-immune disorders 15,16,17,18,19,20.

In sickle cell disease, oxidative stress might play a significant role in the pathophysiology of micro-vascular dysfunction and vaso-occlusive disease 21,22. Many factors are already recognized as triggering agents to a vaso-occlusive crisis: ambient temperature changes, infections, hypoxemia, dehydration, acidosis, fatigue and any potential stressful situation 23. For all of these agents, the physiopathology involves oxidative stress $24,25,26,27$, mainly at the endothelium, leading to chronic vascular inflammation 28,29 . Possibly this process can be influenced by air pollution.

Therefore, the aim of this study was to assess the effects of daily air pollutant concentrations on emergency room visits of sickle cell patients living in the city of São Paulo, Brazil, during a fiveyear period using a case-crossover approach, and to examine effect modification by pain, the main clinical manifestation of vaso-occlusive crises, and by respiratory infections.

\section{Methods}

This is a time-series ecological study using secondary data.

\section{Health data}

We obtained daily counts of children and adolescents' sickle cell disease emergency room (ER) visits from the Emergency Unit of the Clinicas Hospital Children's Institute at the University of São Paulo Faculty of Medical Sciences. The consultations occurred from September 1, 1999 to December 31, 2004 and were stratified according to two main causes: pain crises and respiratory infections.

\section{Environmental data}

Daily records of carbon monoxide (CO), particulate matter with an aerodynamic profile $\leq 10 \mu \mathrm{m}$ $\left(\mathrm{PM}_{10}\right)$, nitrogen dioxide $\left(\mathrm{NO}_{2}\right)$, sulfur dioxide $\left(\mathrm{SO}_{2}\right)$ and ozone $\left(\mathrm{O}_{3}\right)$ were obtained from the São Paulo State Environmental Agency (CETESB). There were 14 monitoring stations spread across the city, although not all of them being fit to measure all types of pollutants. We thus adopted the average of all stations that measured each pollutant as a citywide exposure level. CO was measured using non-dispersive infrared technique and we adopted the highest eight-hour moving average at eight stations. For $\mathrm{NO}_{2}-$ measured by chemiluminescence - and $\mathrm{O}_{3}$ - measured by ultraviolet radiation - we took into consideration the highest hourly average in seven and six stations, respectively. In the case of both $\mathrm{PM}_{10}$ measured by beta radiation in 14 stations - and $\mathrm{SO}_{2}-$ measured by ultraviolet laser pulse at six stations - we adopted the 24-hour averages. All pollutant measurements were taken during the period from 1:00am to $12: 00 \mathrm{pm}{ }^{30}$. Daily minimum temperature and daily mean relative humidity levels were obtained from the Institute of Astronomy and Geophysics (IAG) of the University of São Paulo.

\section{Statistical analysis of air pollutants health effects}

We investigated the association between daily concentrations of air pollutants and emergency room visits of all patients under 18 years of age with sickle cell disease using a case-crossover design. Because this is considered a rare event analysis were not stratified by age groups.

We defined the referent exposure days using the time-stratified approach such that exposures on the case day were compared to exposures on 
days of the same month with the same value of temperature as the case day, controlling for day of the week. Season, weather, and slowly varying covariates were controlled for by matching. We also adopted models where exposures on the case day were compared to exposures on the same day of the week or on every third day. In the model where we matched by day of the week, we also controlled for minimum temperature 14,31.

First we examined the association between air pollution and sickle cell disease, then we examined the air pollution effects on the two main causes of sickle cell emergency room visits, and repeated the analysis stratified by pain and respiratory infections.

The analysis was conducted for each pollutant separately and modeled linearly. In order to explore the lag structure between exposure and effects, we examined the effects of exposure from lag day 0 to lag day 13 and using the moving averages. For instance, a 2-day moving average is the mean of the levels in the concurrent day and the previous day. Results were presented as percentage increases with $95 \%$ confidence intervals in total emergency room visits for an interquartile increase in air pollution.

The data were analyzed using a conditional logistic regression (PROC PHREG, release 8.2; SAS Inst., Cary, U.S.A.).

The Ethics Research Committee of the Clinicas Hospital at the University of São Paulo Faculty of Medical Sciences approved this study.

\section{Results}

From September 1, 1999 to December 31, 2004, there were 3,180 consultations by patients with sickle cell disease at the emergency room service of the Children's Institute. Among those, 1,508 consultations were due to pain, the main clinical manifestation of vaso-occlusive crisis; 775 were due to respiratory infections; and 897 presented other types of infections and/or different problems. The age of the children and adolescents ranged from 1 to 18 years, with a mean of 11 years $( \pm 5.1)$

Table 1 shows the descriptive analysis of both the health and environmental variables used in the study. Sickle cell disease ER visits are presented for all patients and by visits due to specific causes, i.e. pain and respiratory infections.

$\mathrm{SO}_{2}$ was the only pollutant that did not surpass its Brazilian air quality standards through the whole period of study. $\mathrm{PM}_{10}$ mean value was below the quality standards while the daily maximum level $\left(150 \mu \mathrm{g} / \mathrm{m}^{3}\right)$ was exceeded twice. $\mathrm{NO}_{2}$ mean value $\left(100 \mu \mathrm{g} / \mathrm{m}^{3}\right)$ was surpassed on two days and the same timeframe observed for its one-hour maximum value $\left(320 \mu \mathrm{g} / \mathrm{m}^{3}\right)$. The maximum eight-hour moving average for $\mathrm{CO}(9 \mathrm{ppm})$ was exceeded on five days while the Ozone onehour maximum value $\left(160 \mu \mathrm{g} / \mathrm{m}^{3}\right)$ was exceeded on 194 days.

Pearson correlation coefficients (Table 2) show a strong correlation among primary pol-

Table 1

Descriptive analysis of the variables used in the study.

\begin{tabular}{|c|c|c|c|c|c|}
\hline Variables & Daily mean & SD & Minimum & IQR & Maximum \\
\hline \multicolumn{6}{|l|}{ Sickle cell } \\
\hline Total & 1.63 & 1.68 & 0 & - & 9 \\
\hline Pain & 0.78 & 1.01 & 0 & - & 7 \\
\hline Respiratory & 0.40 & 0.74 & 0 & - & 8 \\
\hline \multicolumn{6}{|l|}{ Air pollutant } \\
\hline $\mathrm{PM}_{10}\left(\mu \mathrm{g} / \mathrm{m}^{3}\right)$ & 47.23 & 21.58 & 9.62 & 25.90 & 168.98 \\
\hline $\mathrm{O}_{3}\left(\mu \mathrm{g} / \mathrm{m}^{3}\right)$ & 90.73 & 43.65 & 13.42 & 57.23 & 282.03 \\
\hline $\mathrm{SO}_{2}\left(\mu \mathrm{g} / \mathrm{m}^{3}\right)$ & 14.76 & 6.78 & 2.14 & 8.08 & 51.86 \\
\hline CO (ppm) & 2.63 & 1.2 & 0.54 & 1.25 & 12.09 \\
\hline $\mathrm{NO}_{2}\left(\mu \mathrm{g} / \mathrm{m}^{3}\right)$ & 104.59 & 48.56 & 22.24 & 64.77 & 390.7 \\
\hline \multicolumn{6}{|l|}{ Weather } \\
\hline Temperature $\left({ }^{\circ} \mathrm{C}\right)$ * & 15.23 & 3.40 & -0.20 & 5.00 & 21.80 \\
\hline Humidity $(\%) * \star$ & 79.52 & 8.58 & 45.54 & 10.6 & 97.29 \\
\hline
\end{tabular}

IQR: interquartile range; SD: standard deviation of the mean.

* Minimum temperature;

** Relative air humidity. 
Pearson's correlation coefficients between air pollutants and weather variables.

\begin{tabular}{|c|c|c|c|c|c|c|c|}
\hline & $\mathrm{PM}_{10}$ & $\mathrm{CO}$ & $\mathrm{NO}_{2}$ & $\mathrm{SO}_{2}$ & $\mathrm{O}_{3}$ & Temperature * & Humidity ** \\
\hline $\mathrm{PM}_{10}$ & 1.00 & & & & & & \\
\hline $\mathrm{CO}$ & $0.70 * \star \star$ & 1.00 & & & & & \\
\hline $\mathrm{NO}_{2}$ & $0.64^{\star \star \star}$ & $0.60 * \star \star$ & 1.00 & & & & \\
\hline $\mathrm{SO}_{2}$ & $0.76^{\star \star \star}$ & $0.60 * \star \star$ & 0.60 & 1.00 & & & \\
\hline $\mathrm{O}_{3}$ & 0.40 & $0.08 * \star \star$ & $0.43 * \star \star$ & $0.24 * \star \star$ & 1.00 & & \\
\hline Temperature * & $-0.20 \star \star \star$ & 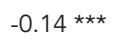 & $-0.09 * \star \star *$ & $-0.28 * \star \star$ & $0.16 * \star \star$ & 1.00 & \\
\hline Humidity ** & 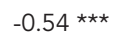 & $-0.33^{\star \star \star}$ & $-0.34 * \star \star$ & $-0.45 * \star \star$ & $-0.40 * \star \star$ & $0.07^{\star \star \star *}$ & 1.00 \\
\hline
\end{tabular}

* Minimum temperature;

** Relative humidity;

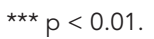

lutants, mainly between $\mathrm{PM}_{10}$ and $\mathrm{SO}_{2}$. Ozone showed an unexpected positive, statistically significant association with $\mathrm{NO}_{2}$, one of its main precursors. Humidity presented negative and sizable correlations with particles and gaseous pollutants, while minimum temperature presented negative correlations with all other pollutants but ozone.

As effects of all pollutants were statistically significant starting at lag zero until no more than three days after exposure we presented them in the following figures with the effects of moving averages from two to four days.

Figure 1 shows the estimated percentage increases and $95 \%$ confidence intervals for total sickle cell emergency room visits resulting from interquartile range increases in air pollutants. Primary pollutants presented quite similar time lag structures. The effects were acute, starting at lag $0\left(\mathrm{PM}_{10}: 11.2 \%, 95 \% \mathrm{CI}: 5.7-16.7 ; \mathrm{NO}_{2}: 11 \%\right.$, 95\%CI: 4.0-17.9; $\mathrm{SO}_{2}$ : 8.2\%, 95\%CI: 2.8-13.6; CO: 6.1\%, 95\%CI: 1.1-11.2) and remained almost unchanged until lag 2 when they dropped. The cumulative effect assessed though moving averages showed remarkable increases, ranging from $10 \%$ to $20 \%$ (4-day moving averages). Ozone presented a different behavior, with a more delayed effect (8.2\%, 95\%CI: 2.6-13.7; only at lag 2).

Figures 2 and 3 show stratified analyses according to the two most common causes of emergency room visits among patients with sickle cell disease: pain crises and respiratory infections.

Figure 2 shows estimated percentage increases and 95\% confidence intervals for sickle cell emergency room visits of patients with pain for interquartile range increases in air pollutants. The effects were higher than those observed for the total ER visits for all primary pollutants. Only ozone presented effects on pain visits with the same degree as observed for total visits.

While analyzing the effects of air pollutants on ER visits of sickle cell patients with respiratory infections, it was noticed that the effects sizes were smaller than those observed for pain crises visits (Figure 3). Increases in ER visits of sickle cell patients with pain due to an interquartile range increase of the four-day moving averages of $\mathrm{PM}_{10}$, for instance, were about 2.0 times bigger than those of sickle cell patients with respiratory diseases (21.1\%, 95\%CI: 9.8-32.4; and 11.5\%, 95\%CI: -2.3-27.6, respectively).

\section{Discussion}

This study reinforces the concept that ambient air pollution variations can trigger vaso-occlusive events in children and adolescents with sickle cell disease.

The air pollution effect on daily number of sickle cell patients emergency room visits was acute and predominantly on pain manifestation, which is a cardinal sign of vaso-occlusion crisis. The effect observed on the respiratory infection ER visits was smaller than the one observed for pain crisis. It is also worthwhile mentioning that more than one pollutant, i.e. particles $\left(\mathrm{PM}_{10}\right)$ and gaseous pollutants $\left(\mathrm{NO}_{2}, \mathrm{CO}\right.$, and $\left.\mathrm{SO}_{2}\right)$, presented similar impact on the defined outcomes, probably because the primary air pollutants were highly correlated to each other.

In this study we used an approach that was different from the one we normally use in time-series studies carried out in Brazil. The case-crossover study design has been adopted in other countries and alongside with its in- 
Percentage increases and $95 \%$ confidence intervals in total sickle cell emergency room (ER) visits due to inter-quartile range increases in $\mathrm{PM} / 0\left(25.90 \mu \mathrm{g} / \mathrm{m}^{3}\right)$, $\mathrm{NO}_{2}\left(64.77 \mu \mathrm{g} / \mathrm{m}^{3}\right), \mathrm{SO}_{2}\left(8.08 \mu \mathrm{g} / \mathrm{m}^{3}\right), \mathrm{CO}(1.25 \mathrm{ppm})$, and $\mathrm{O}_{3}\left(57.23 \mu \mathrm{g} / \mathrm{m}^{3}\right)$ concentrations, from lag 0 to lag 3 and 2-day, 3-day, and 4-day moving averages.

1a) $\mathrm{PM}_{10}$

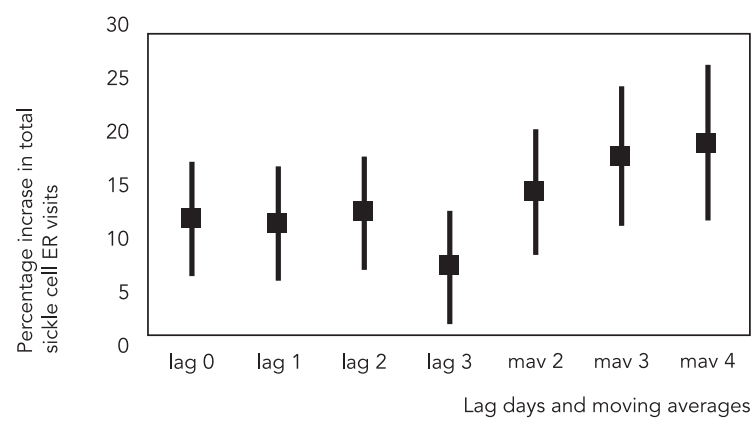

1c) $\mathrm{SO}_{2}$

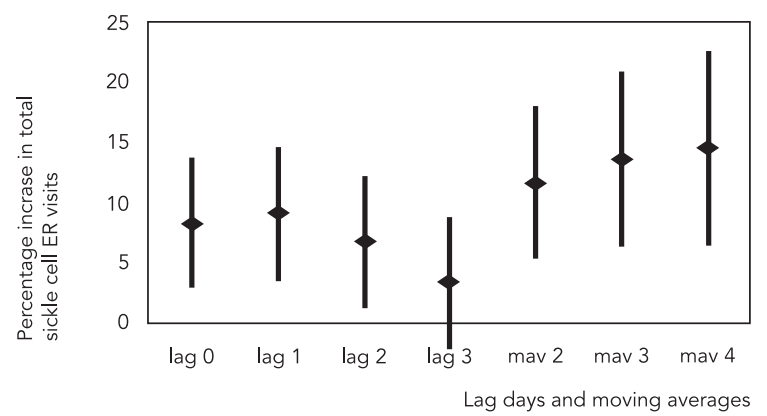

1b) $\mathrm{NO}_{2}$

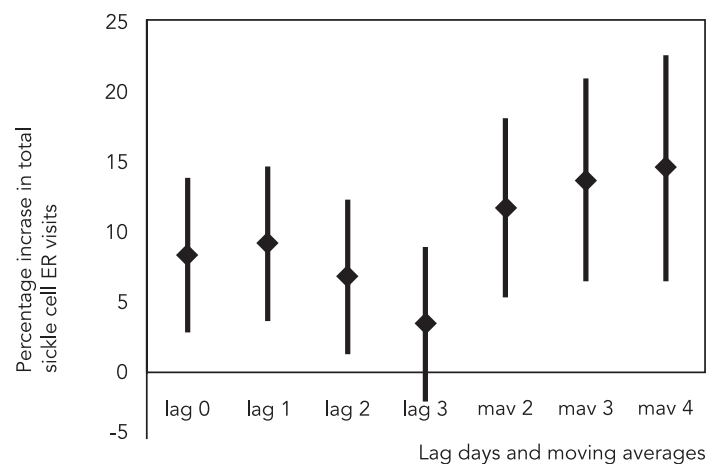

1d) $\mathrm{CO}$

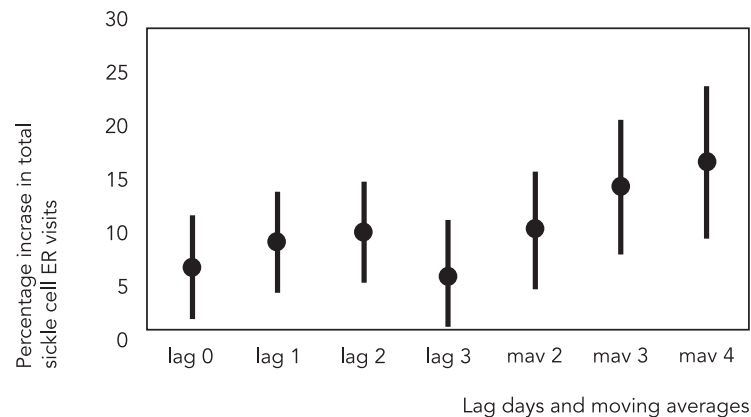

1e) $\mathrm{O}_{3}$

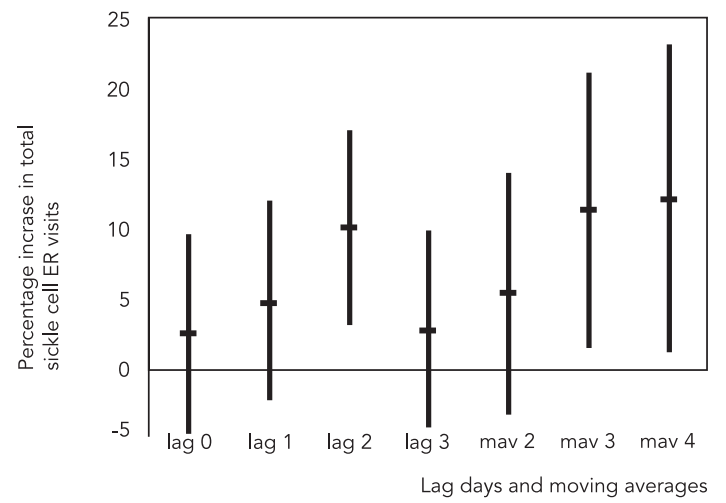

herent qualities it has been initially adopted to confirm results obtained with Poisson regression models. This design samples only cases and compares each subject's exposure experience in a time period just before a case-defining event with that subject's exposure at other times. Because there is perfect matching on all measured or unmeasured subject characteristics that do 
Figure 2

Percentage increases and $95 \%$ confidence intervals in pain sickle cell emergency room (ER) visits due to inter-quartile range increases in $\mathrm{PM} / 0\left(25.90 \mu \mathrm{g} / \mathrm{m}^{3}\right)$, $\mathrm{NO}_{2}\left(64.77 \mu \mathrm{g} / \mathrm{m}^{3}\right), \mathrm{SO}_{2}\left(8.08 \mu \mathrm{g} / \mathrm{m}^{3}\right), \mathrm{CO}(1.25 \mathrm{ppm})$, and $\mathrm{O}_{3}\left(57.23 \mu \mathrm{g} / \mathrm{m}^{3}\right)$ concentrations, from lag 0 to lag 3 and 2-day, 3-day, and 4-day moving averages.

2a) $\mathrm{PM}_{10}$

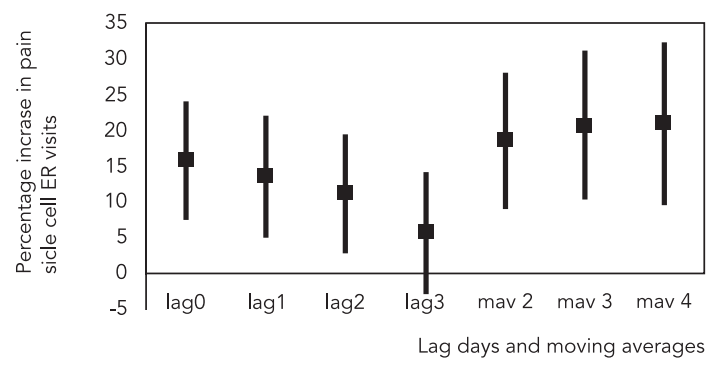

2c) $\mathrm{SO}_{2}$

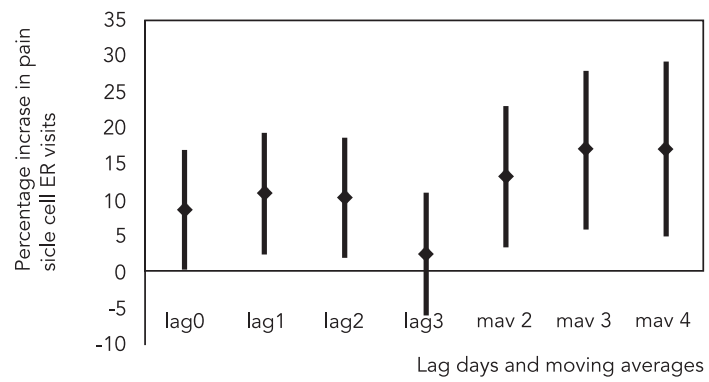

2b) $\mathrm{NO}_{2}$

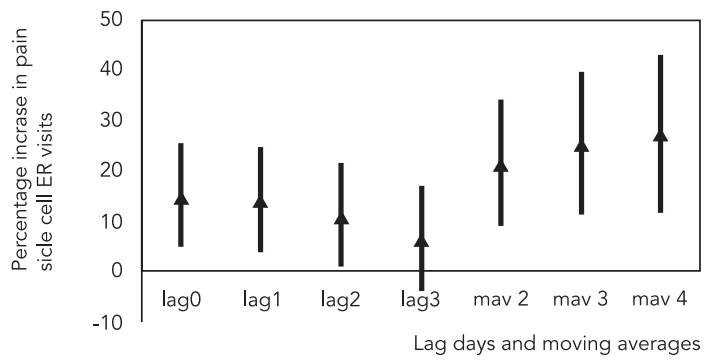

2d) $\mathrm{CO}$

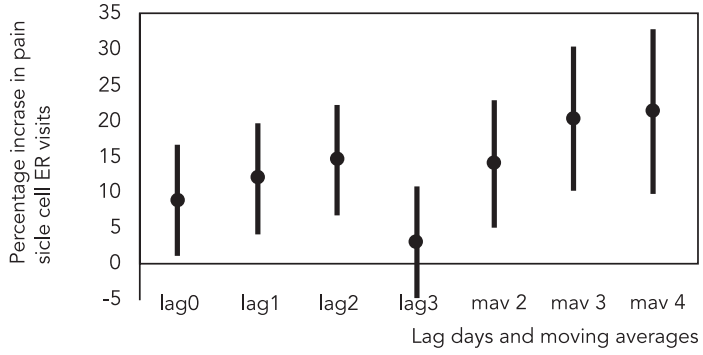

2e) $\mathrm{O}_{3}$

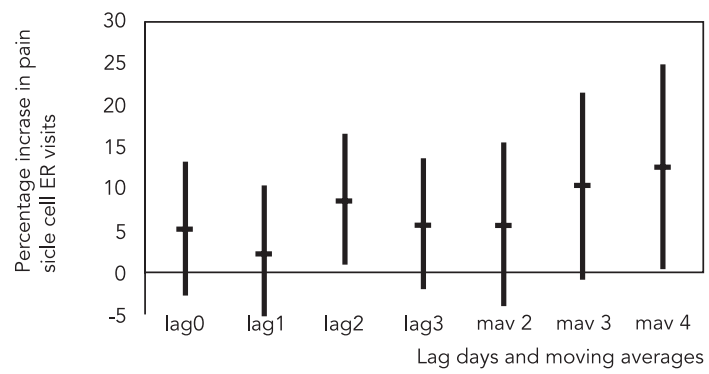

not vary over time, there can be no confounding by those characteristics. If, in addition, the control days are chosen to be close to the event day, matching also controls slowly varying subject characteristics.

In addition, we observed a clear decreasing pattern of the association between exposure to air pollutants and daily number of sickle cell patients' emergency room visits along the stud- ied period after lag 3 . This aspect demands to be investigated using distributed lag non-linear models which will be applied in a 10-year casecrossover study.

There are few studies in the literature evaluating the association between exposure to air pollution and cardiovascular morbidity in healthy children and adolescents 11,12,32,33,34. CalderónGarcidueñas et al. 12 observed a correlation 
Figure 3

Percentage increases and $95 \%$ confidence intervals in respiratory sickle cell emergency room (ER) visits due to inter-quartile range increases in $\mathrm{PM}_{10}$ $\left(25.90 \mu \mathrm{g} / \mathrm{m}^{3}\right), \mathrm{NO}_{2}\left(64.77 \mu \mathrm{g} / \mathrm{m}^{3}\right), \mathrm{SO} 2\left(8.08 \mu \mathrm{g} / \mathrm{m}^{3}\right), \mathrm{CO}(1.25 \mathrm{ppm})$, and $\mathrm{O} 3\left(57.23 \mu \mathrm{g} / \mathrm{m}^{3}\right)$ concentrations, from lag 0 to lag 3 and $2-$ day, $3-$ day, and 4-day moving averages.

3a) $\mathrm{PM}_{10}$

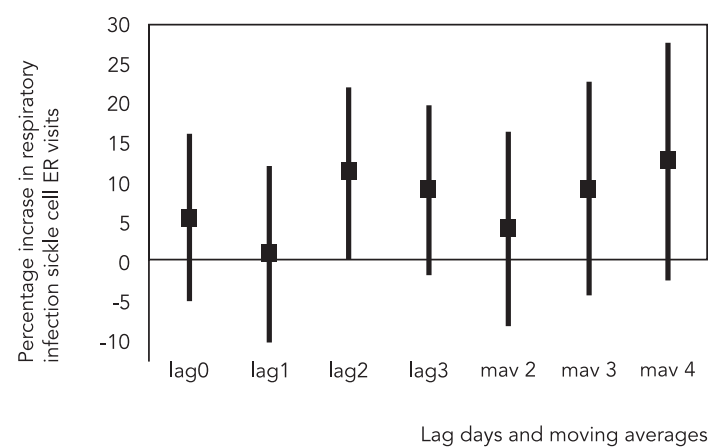

3c) $\mathrm{SO}_{2}$

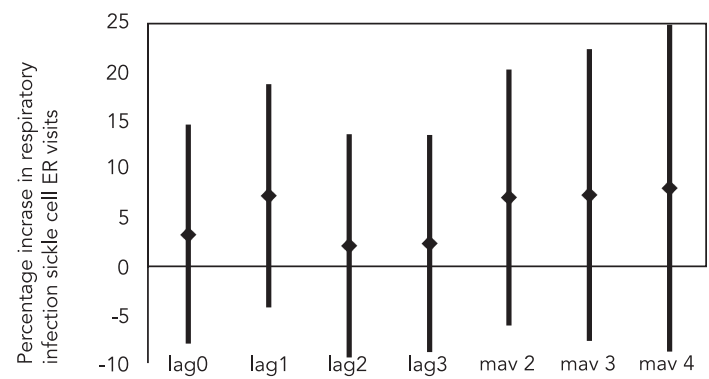

Lag days and moving averages 3b) $\mathrm{NO}_{2}$

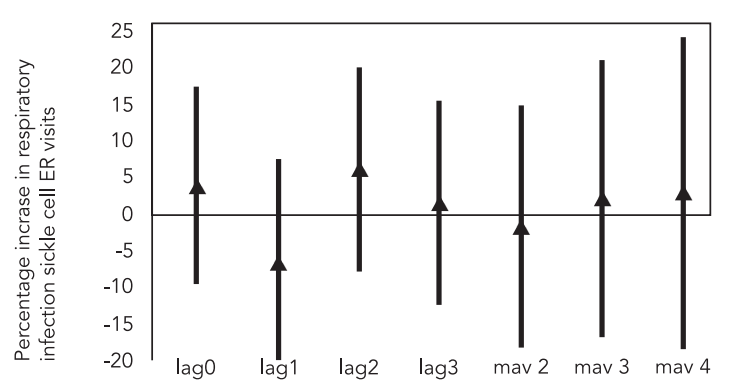

Lag days and moving averages

3d) $\mathrm{CO}$

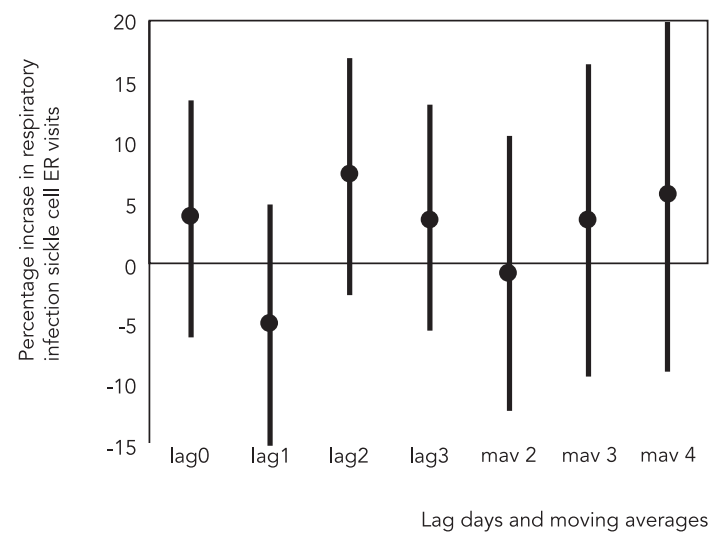

3e) $\mathrm{O}_{3}$

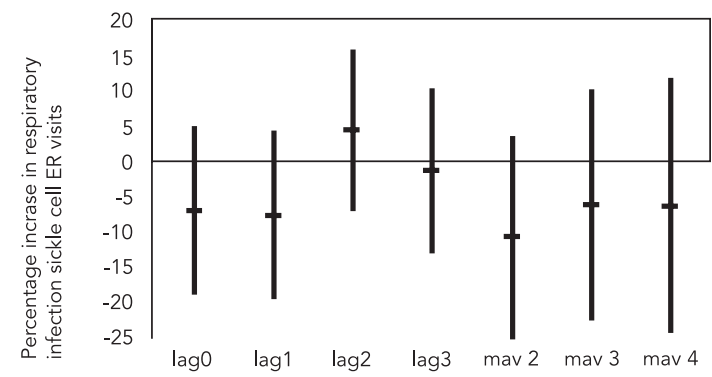

Lag days and moving averages 
between exposure to high concentrations of air pollutants in Mexico City and serum levels of inflammatory mediators, including TNF- alpha, prostaglandin (PG) E2, CRP, interleukin-1 beta, and endothelin-1. Elevated circulating endothelin-1 is very important in the pathophysiological of chronic endothelial dysfunction 35. The balance of pro- and anti-inflammatory mediators as the endothelial activation factors caused by exposure to air pollutants would have an impact in the pathogenesis of cardiovascular damage.

Iannuzzi et al. 33 have found a statistically significant association between carotid arterial stiffness and exposure to air traffic-related pollutants in children living closer to a main street. A recent cross-sectional study showed a significant association between air pollutants and serum thrombomodulin and tissue factor (markers of endothelial dysfunction) in 125 participants aged $10-18$ years 34 . These studies demonstrated that the effects of air pollution on cardiovascular health may affect children.

Although sickle cell disease patients were a higher-risk population of the effects of exposure to air pollution on endothelial dysfunction there are only two studies evaluating these issues. Mittal et al. 36 studied 93 children with sickle cell disease who underwent transcranial Doppler scanning and steady-state blood tests in 2006. The authors found a significant correlation between mean annual exposure to $\mathrm{PM}_{10}$ and extra-cranial internal carotid artery blood.

Yallop et al. 37 in a time series study evaluated an association between air pollution and the numbers of daily admissions with acute sicklecell pain in London (January 1998/October 2001). In the period of the study 1,047 admissions due to acute pain were analyzed. Cross-correlation function analysis showed a significant effect of $\mathrm{O}_{3}$, CO and NO on admissions to hospital with acute pain in sickle cell disease. In our study, we evaluated 1,508 consultations by patients with sickle cell disease at emergency services due to pain with a different study design. We found, controlling for weather variables, a significant association between acute effects of $\mathrm{PM}_{10}, \mathrm{SO}_{2}$, $\mathrm{NO}_{2}$, and $\mathrm{CO}$ and emergency room consultations due to acute sickle-cell pain.

Sickle cell disease is characterized by a continuous and lasting oxidative stress process 22 . Current understanding defines sickle cell disease as a complex chronic disease where high levels of inflammatory mediators (IL-2, IL-4, IL-6, IL-8, - $\alpha$ ) and white cells are observed in patients' blood. Besides vascular constriction and increases in epinephrine, those cells and cytokines lead to an exacerbated adherence of red blood cells in the vascular endothelium and their interaction, triggering vaso-occclusion 22 .

Recently, the understanding of the physiopathologic action of several pollutants on the human body is advancing. Of note, high concentrations of oxidants and pro-oxidants in environmental air, such as $\mathrm{PM}_{2,5}$ and gases can promote oxidative stress 38,39 . The inhaled fine and ultrafine particles may trigger an increase in systemic inflammatory process 3 with increases in the blood's biomarkers of oxidative stress $8,10,11,12,13,40$, hemostatic markers $41,42,43$, as well as an increase in plasma viscosity 44,45 and in injury of endothelial function $3,46,47$. It is observed that conduit and resistance arteriole endothelium-dependent vasodilation can be damaged due to reduced nitric oxide bioavailability as a consequence of systemic pro-inflammatory and oxidative responses ${ }^{3}$.

Of note in sickle cell disease, oxidative stress is involved in several pathophysiologic mechanisms such as endothelial damage, accelerated hemolysis, reduced NO bioavailability and hypercoagulability, potentially contributing to sickle cell disease related vaso-occlusion and pain crisis. Interestingly, the cell-free ferrous hemoglobin in sickle cell disease reduces the NO bioavailability, limiting its anti-thrombotic, antiinflammatory and vasodilatative's properties 22 . In fact, the pathophysiological mechanisms of vascular injury in vaso-occlusive crisis of sickle cell disease have similarities with several mechanisms of vascular damage caused by air pollutants. Our study demonstrated that exposure to air pollution aggravated the vaso-occlusion and pain crisis in the sickle cell disease patients.

In summary, this study showed that the exposure to air pollution generated mainly from automotive fleets in a large urban center can affect the cardiovascular health of children and may promote a significant health burden on a sensitive group, such as sickle cell patients. This result reinforces the relevance of any public policy that could be adopted in order to reduce air pollutant concentrations to ensure safe environments for the development and growth of any citizen, and in particular children and adolescents. 


\section{Resumen}

El objetivo de este estudio fue evaluar la asociación en tre la contaminación atmosférica y las visitas de emergencia de los pacientes pediátricos con anemia de células falciformes. Hemos adoptado un estudio de casos cruzados. Visitas de niños y adolescentes con anemia de células falciformes en urgencias pediátricas, en São Paulo, Brasil, se evaluaron entre 1999 y 2004 con un control de la temperatura, humedad y día de la semana. El rango intercuartil de los promedios móviles de 4 dias de $\mathrm{PM}_{10}, \mathrm{NO}_{2}, \mathrm{SO}_{2}, \mathrm{CO}$ y $\mathrm{O}_{3}$ se asociaron con un aumento del 18,9\% (IC95\%: 11,2-26,5), 19,0\% (IC95\%: 8,3-29,6), 14,4\% (IC95\%: 6,5-22,4), 16,5\% (IC95\%: 8,924,0), y 9,8\% (IC95\%: 1,1-18,6) en el total de visitas, respectivamente. Cuando los análisis se estratificaron por el dolor, se encontró que el $P M_{10}$ mostró una correlación un 40,3\% mayor que la observada en pacientes sin sintomas de dolor. La exposición a la contaminación del aire puede afectar la salud cardiovascular de los niños y puede promover una importante carga para la salud en pacientes con anemia de células falciformes.

Contaminación del Aire; Anemia de Células Falciformes; Servicios Médicos de Urgencia

\section{Contributors}

S. M. M. Barbosa acquired and analyzed the data and wrote the manuscript. S. C. L. Farhat designed the study, analyzed the data, and wrote the manuscript. L. C. Martins designed the study, acquired the data, and wrote the manuscript. L. A. A. Pereira designed the study, acquired the data, and wrote the manuscript. P. H. N. Saldiva designed the study, wrote the article, and revised the final version. A. Zanobetti designed the study, analyzed the data, and wrote the manuscript. A. L. F. Braga designed the study, analyzed the data, wrote the manuscript, and revised the final version.

\section{Acknowledgments}

The authors thank the São Paulo Environmental State Agency (CETESB) for support on air pollution data gathering and interpretation; the division of medical records of the Children's Institute, Clinicas Hospital, University of São Paulo Faculty of Medical Sciences; and the Institute of Astronomy and Geophysics (IAG) at the University of São Paulo for providing meteorological data.

\section{References}

1. Brook RD. Cardiovascular effects of air pollution. Clin Sci (Lond) 2008; 115:175-87.

2. HEI Panel on the Health Effects of Traffic-Related Air Pollution. Traffic-related air pollution: a critical review of the literature on emissions, exposure and health effects. HEI Special Report 17. http:// www.healtheffects.org (accessed on Jan/2010).

3. Brook RD, Rajagopalan S, Pope 3rd CA, Brook JR, Bhatnagar A, Diez-Roux AV, et al. Particulate matter air pollution and cardiovascular disease: an update to the scientific statement from the American Heart Association. Circulation 2010; 121:2331-78.
4. Pope 3rd CA, Dockery DW. Health effects of fine particulate air pollution: lines that connect. J Air Waste Manag Assoc 2006; 56:709-42.

5. Simkhovich BZ, Kleinman MT, Kloner RA. Air pollution and cardiovascular injury epidemiology, toxicology, and mechanisms. J Am Coll Cardiol 2008; 52:719-26.

6. Rückerl R, Greven S, Ljungman P, Aalto P, Antoniades $\mathrm{C}$, Bellander T, et al. Air pollution and inflammation (interleukin-6, C-reactive protein, fibrinogen) in myocardial infarction survivors. Environ Health Perspect 2007; 115:1072-80. 
7. Gong H, Linn WS, Clark KW, Anderson KR, Sioutas C, Alexis NE, et al. Exposures of healthy and asthmatic volunteers to concentrated ambient ultrafine particles in Los Angeles. Inhal Toxicol 2008; 20:533-45.

8. Thompson AM, Zanobetti A, Silverman F, Schwartz J, Coull B, Urch B, et al. Baseline repeated measures from controlled human exposure studies: associations between ambient air pollution exposure and the systemic inflammatory biomarkers IL-6 and fibrinogen. Environ Health Perspect 2010; 118:120-4.

9. Panasevich S, Leander K, Rosenlund M, Ljungman P, Bellander T, de Faire U, et al. Associations of long- and short-term air pollution exposure with markers of inflammation and coagulation in a population sample. Occup Environ Med 2009; 66:747-53.

10. Kelishadi R, Mirghaffari N, Poursafa P, Gidding SS. Lifestyle and environmental factors associated with inflammation, oxidative stress and insulin resistance in children. Atherosclerosis 2009; 203 : 311-9.

11. Chuang KJ, Chan CC, Su TC, Lee CT, Tang CS. The effect of urban air pollution on inflammation, oxidative stress, coagulation, and autonomic dysfunction in young adults. Am J Respir Crit Care Med 2007; 176:370-6.

12. Calderón-Garcidueñas L, Villareal-Calderon R, Valencia-Salazar G, Henriquez-Roldán C, Gutiérrez-Castrellón P, Torres-Jardón R, et al. Systemic inflammation, endothelial dysfunction, and activation in clinically healthy children exposed to air pollutants. Inhal Toxicol 2008; 20:499-506.

13. Calderón-Garcidueñas L, Macías-Parra M, Hoffmann HJ, Valencia-Salazar G, Henríquez-Roldán $\mathrm{C}$, Osnaya N, et al. Immunotoxicity and environment: immunodysregulation and systemic inflammation in children. Toxicol Pathol 2009; 37:161-9.

14. Zanobetti A, Schwartz J. The effect of particulate air pollution on emergency admissions for myocardial infarction: a multicity case-crossover analysis. Environ Health Perspect 2005; 113:978-82.

15. Zeft AS, Prahalad S, Lefevre S, Clifford B, McNally B, Bohnsack JF, et al. Juvenile idiopathic arthritis and exposure to fine particulate air pollution. Clin Exp Rheumatol 2009; 27:877-84.

16. Santos UP, Terra-Filho M, Lin CA, Pereira LA, Vieira TC, Saldiva PH, et al. Cardiac arrhythmia emergency room visits and environmental air pollution in Sao Paulo, Brazil. J Epidemiol Community Health 2008; 62:267-72.

17. Seven A, Guzel S, Aslan M, Hamuryudan V. Lipid, protein, DNA oxidation and antioxidant status in rheumatoid arthritis. Clin Biochem 2008; 41: 538-43.

18. Bernatsky S, Fournier M, Pineau CA, Clarke AE, Vinet E, Smargiassi A. Associations between ambient fine particulate levels and disease activity in patients with systemic lupus erythematosus (SLE). Environ Health Perspect 2011; 119:45-9.
19. Vidotto JP, Pereira LA, Braga AL, Silva CA, Sallum AM, Campos LM, et al. Atmospheric pollution: influence on hospital admissions in paediatric rheumatic diseases. Lupus 2012; 21:526-33.

20. Farhat SC, Silva CA, Orione MA, Campos LM, Sallum AM, Braga AL. Air pollution in autoimmune rheumatic diseases: a review. Autoimmun Rev 2011; 11:14-21.

21. Klings ES, Farber HW. Role of free radicals in the pathogenesis of acute chest syndrome in sickle cell disease. Respir Res 2001; 2:280-5.

22. Nur E, Biemond BJ, Otten HM, Brandjes DP, Schnog JJ; CURAMA Study Group. Oxidative stress in sickle cell disease: pathophysiology and potential implications for disease management. Am J Hematol 2011; 86:484-9.

23. Ballas SK. Pain management of sickle cell disease Hematol Oncol Clin North Am 2005; 19:785-802.

24. Nagababu E, Fabry ME, Nagel RL, Rifkind JM. Heme degradation and oxidative stress in murine models for hemoglobinopathies: thalassemia, sickle cell disease and hemoglobin $\mathrm{C}$ disease. Blood Cells Mol Dis 2008; 41:60-6.

25. Rice-Evans C, Omorphos SC, Baysal E. Sickle cell membranes and oxidative damage. Biocheml J 1986; 237:265-9.

26. Stuart MJ, Nagel RL. Sickle-cell disease. Lancet 2004; 364:1343-60.

27. van den Berg JJ, Kuypers FA, Lubin BH, Roelofsen B, Op den Kamp JA. Direct and continuous measurement of hydroperoxide-induced oxidative stress on the membrane of intact erythrocytes. Free Radic Biol Med 1991; 11:255-61.

28. Chiang EY, Frenette PS. Sickle cell vaso-occlusion. Hematol Oncol Clin North Am 2005; 19:771-84.

29. Platt OS. Sickle cell anemia as an inflammatory disease. J Clin Invest 2000; 106:337-8.

30. Companhia de Tecnologia de Saneamento Ambiental. Rede de monitoramento. http://sistemasinter.cetesb.sp.gov.br/ar/ar_automatica.asp (accessed on Dec/2013).

31. Bateson T, Schwartz J. Who is sensitive to the effects of particulate air pollution on mortality? A case-crossover analysis of effect modifiers. Epidemiology 2004; 15:143-9.

32. Calderón-Garcidueñas L, Vincent R, Mora-Tiscareño A, Franco-Lira M, Henríquez-Roldán C, Barragán-Mejía G, et al. Elevated plasma endothelin-1 and pulmonary arterial pressure in children exposed to air pollution. Environ Health Perspect 2007; 15:1248-53.

33. Iannuzzi A, Verga MC, Renis M, Schiavo A, Salvatore V, Santoriello C, et al. Air pollution and carotid arterial stiffness in children. Cardiol Young 2010; 20:186-90.

34. Poursafa P, Kelishadi R, Lahijanzadeh A, Modaresi M, Javanmard SH, Assari R, et al. The relationship of air pollution and surrogate markers of endothelial dysfunction in a population-based sample of children. BMC Public Health 2011; 11:115.

35. Davenport AP, Maguire JJ. Endothelin. Handb Exp Pharmacol 2006; (176 Pt 1):295-329. 
36. Mittal H, Roberts L, Fuller GW, O'Driscoll S, Dick MC, Height SE, et al. The effects of air quality on haematological and clinical parameters in children with sickle cell anaemia. Ann Hematol 2009; 88:529-33.

37. Yallop D, Duncan ER, Norris E, Fuller GW, Thomas $\mathrm{N}$, Walters J, et al. The associations between air quality and the number of hospital admissions for acute pain and sickle-cell disease in an urban environment. Br J Haematol 2007; 136:844-8.

38. Kelly FJ. Oxidative stress: its role in air pollution and adverse health effects. Occup Environ Med 2003; 60:612-6.

39. Lodovici M, Bigagli E. Oxidative stress and air pollution exposure. J Toxicol 2011; 2011:487074.

40. Delfino RJ, Staimer N, Tjoa T, Arhami M, Polidori A, Gillen DL, et al. Air pollution exposures and circulating biomarkers of effect in a susceptible population: clues to potential causal component mixtures and mechanisms. Environ Health Perspect 2009; 117:1232-8.

41. Ghio AJ, Hall A, Bassett MA, Cascio WE, Devlin RB. Exposure to concentrated ambient air particles alters hematologic indices in humans. Inhal Toxicol 2003; 15:1465-78.
42. Mills NL, Törnqvist H, Robinson SD, Gonzalez M, Darnley K, MacNee W, et al. Diesel exhaust inhalation causes vascular dysfunction and impaired endogenous fibrinolysis. Circulation 2005; 112: 3930-6.

43. Samet JM, Graff D, Berntsen J, Ghio AJ, Huang YC, Devlin RB. A comparison of studies on the effects of controlled exposure to fine, coarse and ultrafine ambient particulate matter from a single location. Inhal Toxicol 2007; 19 Suppl:29-32.

44. Pekkanen J, Brunner EJ, Anderson HR, Tiittanen P, Atkinson RW. Daily concentrations of air pollution and plasma fibrinogen in London. Occup Environ Med 2005; 57:818-22.

45. Schwartz J. Air pollution and blood markers of cardiovascular risk. Environ Health Perspect 2001; 109:405-9.

46. Rajagopalan S, Sun Q, Chen LC. Particulate pollution and endothelial function: déjà vu all over again in the air. Circulation 2005; 111:2869-71.

47. Peretz A, Sullivan JH, Leotta DF, Trenga CA, Sands FN, Allen J, et al. Diesel exhaust inhalation elicits acute vasoconstriction in vivo. Environ Health Perspect 2008; 116:937-42.

Submitted on 28/Jan/2014

Final version resubmitted on 17/Aug/2014

Approved on 12/Sep/2014 